\title{
Controlling - Striving for Excellence Implementation of Model Solutions in Organizations Operating in Poland
}

\author{
Agnieszka Bieńkowska \\ Professor of WUST, Wroclaw University of Science and Technology, Wybrzeże Wyspiańskiego 27, 50-370 \\ Wroclaw, Poland, agnieszka.bienkowska@pwr.wroc.pl
}

Received (28.11.2018.); Revised (08.01.2019.); Accepted (05.02.2019.)

\begin{abstract}
The article discusses the issue of controlling changes over time in organizations operating in Poland. Reference has been made to the model controlling solutions proposed by A. Bieńkowska [2015], which should ensure that the maximum possible benefits from the implementation of controlling are achieved with certain costs in this respect. It has been hypothesized that in the process of achieving controlling excellence, the percentage of organizations using model solutions should increase, due to the fact that the use of such solutions results in an increase in the effectiveness of controlling, followed by the increase of quality of management and the organizational performance. In order to verify the adopted hypothesis, comparative studies of the frequency of use of controlling model solutions in 2009 and in 2011-2014 were conducted. The sample was not representative but diversified and included 306 organizations in research from 2009 (164 of them declared the use of controlling) and 412 organizations in the studies from 2011-2014 (238 of them declared the use of controlling). Statistical verification of differences in both groups was carried out using cross tables with chi-square statistics. The results of the study allow to accept the hypothesis that in the process of striving for excellence (in time) there is a spontaneous increase in the degree of implementation of the model controlling solutions due to the maximization of the benefits possible to obtain due to the implementation of controlling.
\end{abstract}

Key words: controlling, model controlling solutions, excellence

\section{INTRODUCTION}

In Poland, controlling appeared after 1989, during the transformation of the economic system. The introduction of the principles of free market economy enabled Western investors to expand to the Polish market, which meant not only the inflow of capital to Polish organizations, but also the possibility of using new Western European technologies and modern management solutions. Controlling came to Poland from Germany, so the original idea of Polish controlling was more in line with the German assumptions [Horvath, 2002; Horvath, 2009; Becker et al., 2011] than American ones [Jackson, 1949; Bragg, 2004] - although the USA is considered as the cradle of modern controlling. Branches of Western European organizations (especially German) established in Poland were the pioneers, and then specific benchmarks in the field of controlling in Poland. Initially, the solutions of the discussed management method were implemented in those organizations. In the 1990s, the controlling solutions were implemented more or less successfully in organizations without the participation of foreign capital [Bieńkowska, 2015, p. 19-21]. During this period, the first scientific publications in this field appeared, focusing primarily on the essence of the phenomenon and the attempt to define this new concept in Poland [cf. e.g. Goliszewski, 1991; Wierzbicki, 1994; Haładryj, 1991].

Nowadays, controlling is understood as "a method of management support used mainly in the areas of planning and controlling - for the implementation of functions such as information supply, coordination, supervision, monitoring or participation in management; enabling managers - through its measurable and economical overtone - for making rational (and apt) decisions, and thus aimed at achieving the goals of the organization as a whole" [Bieńkowska, 2015, p. 38]. The Polish literature on the subject mentions the "unbelievable growth in interest in controlling in the last decade of the previous century" [Nowak 2004, p. 13]. Without a doubt, contemporary interest in controlling, both in theory and practice, is not declining. On the one hand, it is proven by empirical research findings proving that controlling is one of the management methods most often implemented in Polish organizations [e.g. Bieńkowska, Zgrzywa-Ziemak 2011, p. 214], and on the other hand, there is a growing number of scientists 
representing the so-called young generation [e.g. Nowosielski, Lichtarski, 2006; Nesterak, 2002, Chalastra, 2010, Nowak, 2008, Bieńkowska, Zabłocka, Tworek 2018; Bieńkowska, Zabłocka, Tworek 2019, Tworek 2019], taking up the subject matter of controlling and not only following the example of American or German studies, but using the experience of Polish organizations, which have implemented controlling [Bieńkowska, 2015, p. 23-24].

The currently conducted research in the field of controlling in Poland is diverse and concerns both the functioning of entire controlling in the organization and also functioning of its individual components (controlling solutions). Moreover, this subject changes over time, just as the controlling itself is dynamic. In 2004, E. Nowak [2004, p. 14] claimed that "the concept of controlling is a subject to continuous development, both in theoretical terms and in the area of practical interest; however, in our country, the practice of controlling anticipates to a certain degree the theory". Nowadays, it is still true. What is more, this statement in a way determines the research methodology in the field of modern controlling, where it is more important to observe and analyze changes in the essence of controlling in organizations, than to develop new, purely theoretical concepts "on paper".

One of the most important and current areas of research in the field of controlling is concerning its quality and effectiveness, as well as studies connected with it, concerning the issue of striving for the excellence of controlling solutions, together with the indication of model solutions in that field [Bieńkowska, 2015, p. 24] . "Controlling solutions implemented in the organization evolve in a continuous manner.

They are becoming more "mature" - expanding the scope and depth of implemented solutions in striving for excellence" [Bieńkowska, Tworek, Zabłocka-Kluczka, 2018]. In this context, the question arises, what is the percentage of organizations using model solutions? Should an increase in this percentage be expected in time, which would somehow confirm the organization's drive for the excellence of controlling solutions? Is it possible to aim for a de facto self-optimization of the shape of controlling solutions in the organization? An attempt to answer these questions is the purpose of this study.

\section{MODEL CONTROLLING SOLUTIONS}

The implementation of controlling in the organization is consistent with implementation of a set of controlling solutions. The concept of controlling solutions is understood as " the way in which problems related to controlling are settled in the organization (especially in the functional, organizational and instrumental sphere)" [Bieńkowska, 2015, p. 81].

The literature on the subject distinguishes three groups of controlling solutions: functional, institutional (organizational, structural) and instrumental controlling solutions. Functional solutions of controlling should be considered as primary in relation to organizational and instrumental solutions. Functional solutions include the definition of the controlling objectives and resulting from them functions of controlling, and enable the identification of the reference areas (areas of interest, components) and tasks in each of them. Functional solutions are also an indication of the scope of coordination in controlling. In this case, it may also be important to define the type of controlling implemented in the organization [Bieńkowska, 2015, p. 107]. Institutional controlling solutions are related to the organizational sphere and include, first of all, issues related to the integration of controllers (with defined duties, powers and responsibilities) into the organizational structure. Institutional solutions are also issues related to the implementation of responsibility centers in the organization, i.e. selection of criteria for the separation of responsibility centers, determination of the degree of coverage of the organizational structure by the responsibility centers, identification of the types of responsibility centers, assignment of objectives and tasks, and definition of measurement methods for individual responsibility centers [Bieńkowska, 2015, p. 139]. Instrumental solutions define the range of instruments in the strategic and operational perspective, including in particular the controlling costs and results, budgeting and deviation analysis from the controlling point of view, as well as the controlling information and reporting system [Bieńkowska, 2015, p. 176]. Finally, the choice of the controlling concept is important as a combination of the above-mentioned groups of solutions.

The term controlling concept should be understood as "broad, relatively homogeneous groups of controlling solutions constituting a relatively coherent way of its understanding and functioning. It is a separate, specific way of controlling functioning in the organization, characterized by a specific, peculiar selection of functional, organizational and instrumental controlling solutions " [Bieńkowska, 2015, p. 197].

Within each of the specified groups of functional, organizational or instrumental solutions, one can distinguish many varieties or ways of implementing particular elements of controlling (e.g. controller innovator, navigator or registrar, as well as institutional, non-institutional and mixed form of inclusion of controllers in the organizational structure). There are also many possibilities of composition of these elements, creating a comprehensive concept of controlling in organization (controlling as extended financial accounting, information supply, management coordination or a special form of management), which are often intended for organizations with different characteristics and / or functioning in different external conditions [Bieńkowska, 2015].

Therefore, the scope of controlling solutions surprises with diversity. The selection of the shape of the controlling solutions cannot be accidental. It is obvious that, first and foremost, solutions must be mutually aligned. They should also correspond to external conditions and features of a particular organization, which seems to be a direct consequence of the formation of controlling as a result of practical needs in the field of management - controllers are using instruments adequate to the current problems at a 
given moment in specific organization in the course of implementation of their respective tasks. For this reason, it is obvious that the choice of the shape of controlling solutions is also not straightforward. And if it is imposed by the variability of external determinants or organizational differentiators over time ("controlling must constantly keep up with changes in external and internal conditions (...) look for new solutions" [Grudziński, 2008, p. 13]), it turns out that the implementation of controlling requires specialist knowledge concerning implemented management method, but also concerning the management of the specific organization in which this implementation is taking place. Moreover, it is practically impossible to implement controlling, which is final and fully suited to the needs of the organization - one should rather consider the necessity of its improvement over time.

For this reason, it seems valuable to define universal or based on contingency-theoretical approach recommendations regarding the controlling solutions preferred for the given environment and organizational conditions. In the universalist approach, the essence of the correctness of controlling solutions is to achieve a specific set of these solutions recognized as the solutions of the highest level of maturity, and therefore possible to apply in all organizations, and independent of situational conditions.

However, in the contingency-theoretical approach to controlling solutions, there is the degree of alignment between shape of its solutions to the internal characteristics of the organization (especially its size, organizational structure, etc.) and the conditions of the environment in which the organization operates (especially to its dynamics), and thus specific situational factors [Bieńkowska, 2014, p. 763]. Regardless of the adopted approach, model solutions for controlling should ensure that the maximum possible benefits from the implementation of controlling are achieved with certain costs in this respect.

The quality of controlling solutions affects its effectiveness as well as the quality of organization management and the effectiveness of the organization as a whole [Bieńkowska, 2015, p. 253].

The process of achieving excellence in controlling solutions shape is the separate problem. „Mature controlling is a method, which on the one hand meets the requirements set for it (at least at the minimal (acceptable) level), and on the other hand is able to strive for excellence, adapting to the environment and characteristics of the organization itself. Excellent controlling is a method contextually excellent, understood as model solution, which - in accordance with the theory of situational conditions - is fully adapted to both the characteristics of the organization and the conditions of the environment, in which the organization operates [Bieńkowska, 2015, p. 251]. With regard to controlling, the absolute excellence is impossible.

Moreover, maturity and excellence are both contextually conditioned and are inseparably connected with the assessment" [Bieńkowska, Tworek,
Zabłocka-Kluczka, 2018]. Moreover, in the light of research findings (conducted by A.Bieńkowską, K.Tworek and A. Zabłocką-Kluczkę) and theoretical considerations outlined above, controlling time of use is positively related with the quality of controlling outputs and strongly positively related with all results obtained due to controlling implementation." [Bieńkowska, Tworek, Zabłocka-Kluczka, 2018]. In this context the following hypothesis can be outlined:

$\mathrm{H}$ : In the process of striving for excellence (in time) there is a spontaneous increase in the degree of implementation of the model controlling solutions due to the maximization of the benefits possible to obtain due to the implementation of controlling.

An attempt to verify the above hypothesis will constitute the essence of this study.

\section{RESEARCH METHODOLOGY}

Referring to the outlined hypothesis, a comparison of the results obtained in two studies was used:

1) carried out by the team A. Bieńkowska, Z. Kral, A. Zabłocka-Kluczka in 2009 (RES1);

2) carried out by A. Bieńkowską in 2011-2014 (RES2).

Unfortunately, it will not be possible to compare all the results obtained in the conducted research, due to the fact that the first one was narrower than the second one.

The first study (RES1) concerned the analysis of the shape of functional, organizational and instrumental solutions of controlling in organizations operating in Poland. The research was carried out with a survey (questionnaire) technique. The distribution of the results which were obtained in the research has been presented with relation to the size of organizations, the type of environment, the existence of the implemented controlling system and the controlling time of use. The data was collected in February 2009. 306 survey questionnaires were analyzed, 164 (about 54\%) organizations had controlling implemented. The results of research are described in: [Bieńkowska, Kral, Zabłocka-Kluczka, 2011].

The second study (RES2) referred not only to the identification of the shape of controlling solutions (which was necessary from the point of view of the main research goal), but above all to identify patterns of these solutions from the perspective of their quality identification and efficiency of controlling, as well as the quality of management and organizational performance as the whole. Research on the use of controlling in organizations operating in Poland was conducted in 2011-2014. The research was carried out with a survey (questionnaire) technique.

A total of 412 organizations were surveyed, 238 of them with controlling implemented (about 58\%). A questionnaire was used to diagnose functional, organizational and instrumental solutions of controlling, as well as to evaluate these solutions. The relation between the implementation of controlling and the broadly understood parameters of organization 
functioning was measured. Statistical description and reasoning were used to analyze empirical data.

The results of research were described mainly in: [Bieńkowska, 2015], as well as in [Bieńkowska, 2016].

In both cases, a person responsible for the implementation and functioning of controlling was asked to fill in the questionnaire. If the controlling has not been implemented yet - the authors asked the head of finance/accounting department or a representative of general management.

As a result of both researches, the controlling solutions in the organizations operating in Poland were identified.
The influence of situational factors (such as the size of the organization, the dynamics of the environment) on the use of controlling and shaping its solutions were determined in the organizations operating in Poland. Then, as the results of second research, the validation of the individual solutions was performed and the recommended solutions (benchmark) were identified from the perspective of quality of controlling solution and efficiency of controlling, and - as a result - quality management and organizational performance.

The characteristics of both samples are presented in Table 1.

Table 1. Characteristics of samples from RES1 and RES2.

Source: own work based on [Bieńkowska, Kral, Zabłocka-Kluczka, 2011; Bieńkowska, 2015].

\begin{tabular}{|c|l|c|c|c|c|}
\hline \multirow{3}{*}{ Organization characteristic } & \multicolumn{2}{|c|}{ RES1 } & \multicolumn{2}{c|}{ RES2 } \\
\cline { 2 - 6 } & n.org. & $\%$ & n.org. & $\%$ \\
\hline \multirow{5}{*}{ Size of employment } & below 10 employees & - & - & 6 & 1,5 \\
\cline { 2 - 6 } & 11 to 50 employees & - & - & 34 & 8,3 \\
\cline { 2 - 6 } & 51 to 250 employees & 168 & 54,9 & 176 & 42,7 \\
\cline { 2 - 6 } & 251 to 500 employees & 49 & 16,0 & 68 & 16,5 \\
\cline { 2 - 6 } & 501 to 1000 employees & 37 & 12,1 & 48 & 11,7 \\
\cline { 2 - 6 } & above 1000 employees & 52 & 17,0 & 80 & 19,4 \\
\hline \multirow{5}{*}{$\begin{array}{c}\text { Prevalent } \\
\text { type of activity }\end{array}$} & potal & 306 & 100,0 & 412 & 100,0 \\
\cline { 2 - 6 } & production & 146 & 47,7 & 149 & 36,2 \\
\cline { 2 - 6 } & production and services & 43 & 14,1 & 41 & 10,0 \\
\cline { 2 - 6 } & trade & 31 & 10,1 & 32 & 7,8 \\
\cline { 2 - 6 } & production and trade & - & - & 30 & 7,3 \\
\hline & Total & 306 & 100,0 & 412 & 100,0 \\
\hline
\end{tabular}

\section{IMPLEMENTATION OF MODEL FUNCTIONAL CONTROLLING SOLUTIONS}

As it was written earlier, functional solutions are primary in relation to the other two types of solutions. In a study conducted in 2011, it was found that the model functional solutions of controlling (in terms of the quality of these solutions and the efficiency of controlling, as well as the quality of management and organizational performance) should be adopted as follows:

- (M1) with the increase in the size of the organization, it is reasonable to increase the scope of controllers' tasks;

- $\quad(\mathrm{M} 2)$ assigning a medium range of tasks is particularly recommended for organizations operating in moderately changing and moderately turbulent environments; at the same time, the assignment of a narrow range of tasks should not be advised in these organizations;

- $\quad(\mathrm{M} 3)$ it is reasonable to include controlling in as many areas of the organization as possible; (regardless of situational factors);

- (M4) (concerns the concept of controlling) the bigger the organization, the more justified it is to move away from the concept of controlling as extended management accounting towards controlling as a special form of management; the legitimacy of using the concept of information management support drops sharply in organizations employing more than 250 people, coordination is slightly increasing, and the implementation of the concept of controlling as a special form of management is the most justified in organizations employing more than 250 employees [Bieńkowska, 2015, p. 404; p.434-435].

Unfortunately, the research does not provide the possibility for direct comparisons of the scope of implementation of the first two (M1, M2) model functional solutions of controlling.

However, they show clear tendencies of saturation of two consecutive (M3, M4) model functional solutions of controlling in time. Fig. 1 presents the scope of organization areas covered by controlling in both periods.

Differences between the results obtained in the RES1 and RES2 studies are statistically significant for all areas (besides the production area) (tab.2.), which means that during the analyzed years $(2009 ; 2011$ 2014) there was a clear (statistically significant) increase in the number of areas of organizations covered by controlling in the surveyed organizations, which confirms the $\mathrm{H}$ hypothesis in relation to the M3 model solution. 


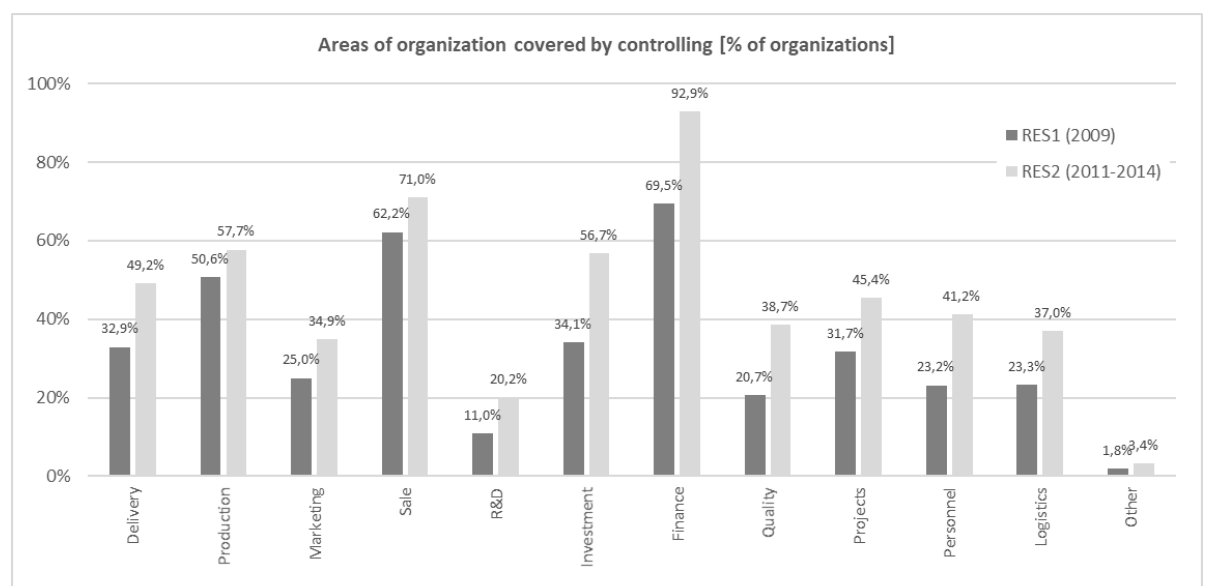

Figure 1. Areas of organizations covered by controlling - comparison of research from 2009 and 2011-2014 r. Source: own work based on [Bieńkowska, Kral, Zabłocka-Kluczka, 2011; Bieńkowska 2015].

Table 2. Characteristics of statistically significant relations between the year of research and the use of controlling in individual areas of the organization. Source: own study

\begin{tabular}{|c|c|}
\hline Areas & $\chi^{2}$ test results \\
\hline \begin{tabular}{|l|} 
Delivery \\
\end{tabular} & $\chi^{2}(1, N=397)=11,732 ; p=0,001^{* *}$ \\
\hline Production & $\chi^{2}(1, N=397)=2,089 ; p=0,148$ \\
\hline Marketing & $\chi^{2}(1, N=397)=5,056 ; p=0,025^{\star \star}$ \\
\hline Sale & $\chi^{2}(1, N=397)=4,400 ; p=0,036^{\star \star}$ \\
\hline R\&D & $\chi^{2}(1, N=397)=6,433 ; p=0,011^{\star \star}$ \\
\hline Investment & $\chi^{2}(1, N=397)=21,311 ; p<0,001^{* *}$ \\
\hline Finance & $\chi^{2}(1, N=397)=47,904 ; p<0,001^{* *}$ \\
\hline Quality & $\chi^{2}(1, N=397)=16,279 ; p<0,001^{* *}$ \\
\hline Projects & $\chi^{2}(1, N=397)=8,580 ; p=0,003^{\star \star}$ \\
\hline Personnel & $\chi^{2}(1, N=397)=15,249 ; p<0,001^{* *}$ \\
\hline Logistics & $\chi^{2}(1, N=397)=9,467 ; p=0,002^{\star *}$ \\
\hline
\end{tabular}

Table 3. and 4. present the frequency of application of individual controlling concepts depending on the size of the organization in both periods. The obtained results are not unambiguous in interpretation. However, the polarization of applied concepts can be noted in RES2 research (2011-2014): in organizations employing up to 250 people, the concept of controlling as an information support for management is most often used, while in larger organizations the concept of controlling as management coordination is most often used, which is in part in agreement with the M4 model solution and at least partially confirms the hypothesis adopted at the beginning of the paper. Both concepts are used in slightly over threequarters of the organizations surveyed. However, the decrease in the frequency of applying the concept of controlling as an extended financial accounting and a special form of management is surprising. However, differences between the results obtained in pairs for individual sizes of the organization in both research periods are statistically insignificant.

Table 3. Frequency of applying particular concepts of controlling depending on the size of the organization - RES1 (2009). Source: own work based on [Bieńkowska, Kral, Zabłocka-Kluczka, 2011].

\begin{tabular}{|c|c|c|c|c|c|c|}
\hline RES1 (2009) & \multicolumn{6}{|c|}{ Size of employment [\% of organizations] } \\
\hline \multirow[t]{3}{*}{ Controlling concept } & $\begin{array}{c}\text { below } \\
50\end{array}$ & $51-250$ & $251-500$ & $501-1000$ & $\begin{array}{c}\text { above } \\
1000\end{array}$ & Total \\
\hline & $\mathrm{N}=0$ & $\mathrm{~N}=59$ & $\mathrm{~N}=27$ & $\mathrm{~N}=30$ & $\mathrm{~N}=48$ & $\mathrm{~N}=164$ \\
\hline & [\%] & [\%] & [\%] & [\%] & [\%] & [\%] \\
\hline Extended financial accounting & 0,0 & 20,3 & 11,1 & 6,7 & 6,3 & 12,2 \\
\hline Information support for management & 0,0 & 27,1 & 29,6 & 43,3 & 22,9 & 29,3 \\
\hline Management coordination & 0,0 & 35,6 & 44,4 & 36,7 & 35,4 & 37,2 \\
\hline Special form of management & 0,0 & 16,9 & 14,8 & 13,3 & 35,4 & 21,3 \\
\hline Total & 0,0 & 100,0 & 100,0 & 100,0 & 100,0 & 100,0 \\
\hline
\end{tabular}


Table 4. Frequency of applying particular concepts of controlling depending on the size of the organization - RES2 (20112014). Source: own work based on [Bieńkowska, 2015].

\begin{tabular}{|c|c|c|c|c|c|c|}
\hline RES2 (2011-2014) & \multicolumn{6}{|c|}{ Size of employment [\% of organizations] } \\
\hline Controlling concept & $\begin{array}{c}\text { below } \\
50\end{array}$ & $51-250$ & $251-500$ & $501-1000$ & $\begin{array}{c}\text { above } \\
1000\end{array}$ & Total \\
\hline & $\mathrm{N}=6$ & $\mathrm{~N}=66$ & $\mathrm{~N}=50$ & $\mathrm{~N}=42$ & $\mathrm{~N}=69$ & $\mathrm{~N}=233$ \\
\hline & [\%] & [\%] & [\%] & [\%] & [\%] & [\%] \\
\hline Extended financial accounting & 0,0 & 9,1 & 8,0 & 11,9 & 4,3 & 7,9 \\
\hline Information support for management & 50,0 & 40,9 & 34,0 & 35,7 & 34,8 & 36,6 \\
\hline Management coordination & 16,7 & 34,8 & 52,0 & 40,5 & 37,7 & 40,5 \\
\hline Special form of management & 33,3 & 15,2 & 6,0 & 11,9 & 23,2 & 15,0 \\
\hline Total & 100,0 & 100,0 & 100,0 & 100,0 & 100,0 & 100,0 \\
\hline
\end{tabular}

\section{IMPLEMENTATION OF MODEL ORGANIZATIONAL CONTROLLING SOLUTIONS}

In the research conducted in 2011 , it was stated that as model organizational solutions of controlling (in terms of the quality of these solutions and the efficiency of controlling, as well as the quality of management and organizational performance), should be as follows:

-(M5) the bigger the organization, the more reasonable it is for the controlling body to take the institutional form;

-(M6) the more dynamic the environment, the more reasonable it is that the position of the main controller takes the institutional form;

-(M7) it is reasonable for the controllers to have wide decision-making powers;

-(M8) it is reasonable to implement the resultant and investment centers rather than lack of their implementation, it is reasonable to distinguish centers with high decision-making independence;

-(M9) it is reasonable to distinguish various centers of responsibility regardless of situational factors;

-(M10) it is reasonable for the responsibility centers to be more aggregated than fragmented [Bieńkowska, 2015, p. 434-435].

Also, in relation to the application of model solutions in the scope of organizational solutions, there are differences between the results of tests carried out in the two analyzed periods. In tab. 5. and tab.6. the frequency of application of particular forms of inclusion of the controller into the organizational structure (controller from the outside, controllers in the already existing department in the organization, controllers in a special department separated for controlling needs, or controllers located in various places in the organizational structure) is presented depending on the size of the organization, referring to M5 model solution: the bigger the organization, the more justified it is for the controlling body to take the institutional form than the other. Differences in pairs between the results obtained for individual sizes of the organization in both research periods are statistically insignificant. However, it can be noticed that for organizations employing up to 250 people, there is a decrease in the percentage of separation of an independent controlling department and increase of controllers' inclusion in the already existing department in the organization, and of controllers located in various places in the organizational structure. At the same time, in very large organizations employing over 1000 people, the percentage of organizations deciding to separate a department dedicated to controlling is increasing, and the percentage of organizations that assign controlling tasks to an already existing departments in the organization is decreasing. The observed trends do not explicitly confirm the presented hypothesis with reference to the M5 standard, however they do not allow for its rejection.

Table 5. Forms of including controllers into organizational structure depending on the size of the organization -RES1 (2009). Source: own work based on [Bieńkowska, Kral, Zabłocka-Kluczka, 2011].

\begin{tabular}{|l|c|c|c|c|c|c|}
\hline \multicolumn{2}{|c|}{ RES1 (2009) } & \multicolumn{5}{|c|}{ Size of employment [\% of organizations] } \\
\hline \multirow{2}{*}{$\begin{array}{c}\text { Forms of including controllers into } \\
\text { organizational structure }\end{array}$} & $\begin{array}{c}\text { below } \\
50\end{array}$ & $51-250$ & $251-500$ & $501-1000$ & $\begin{array}{c}\text { above } \\
1000\end{array}$ & Total \\
\cline { 2 - 7 } & $\mathrm{N}=0$ & $\mathrm{~N}=48$ & $\mathrm{~N}=25$ & $\mathrm{~N}=28$ & $\mathrm{~N}=47$ & $\mathrm{~N}=148$ \\
\cline { 2 - 7 } & {$[\%]$} & {$[\%]$} & {$[\%]$} & {$[\%]$} & {$[\%]$} & {$[\%]$} \\
\hline Controller from the outside & 0,0 & 4,2 & 0,0 & 3,6 & 0,0 & 2,0 \\
\hline $\begin{array}{l}\text { Controllers in the already existing } \\
\text { department in the organization (e.g. } \\
\text { Department of management accounting) }\end{array}$ & 0,0 & 22,9 & 24,0 & 10,7 & 25,5 & 21,6 \\
\hline $\begin{array}{l}\text { Controllers in the special department } \\
\text { separated for controlling needs (e.g. } \\
\text { controlling department) }\end{array}$ & 0,0 & 58,3 & 64,0 & 78,6 & 53,2 & 61,5 \\
\hline $\begin{array}{l}\text { Controllers located in various places in the } \\
\text { organizational structure }\end{array}$ & 0,0 & 14,6 & 12,0 & 7,1 & 21,3 & 14,9 \\
\hline \multicolumn{1}{|c|}{ Total } & 0,0 & 100,0 & 100,0 & 100,0 & 100,0 & 100,0 \\
\hline
\end{tabular}


Table 6. Forms of including controllers into organizational structure depending on the size of the organization -RES2

(2011-2014). Source: own work based on [Bieńkowska 2015].

\begin{tabular}{|c|c|c|c|c|c|c|}
\hline RES2 (2011-2014) & \multicolumn{6}{|c|}{ Size of employment [\% of organizations] } \\
\hline \multirow{3}{*}{$\begin{array}{l}\text { Forms of including controllers into } \\
\text { organizational structure }\end{array}$} & $\begin{array}{l}\text { below } \\
50\end{array}$ & $51-250$ & $251-500$ & $501-1000$ & $\begin{array}{l}\text { above } \\
1000\end{array}$ & Total \\
\hline & $\mathrm{N}=4$ & $\mathrm{~N}=60$ & $\mathrm{~N}=48$ & $\mathrm{~N}=38$ & $\mathrm{~N}=62$ & $\mathrm{~N}=212$ \\
\hline & [\%] & [\%] & [\%] & [\%] & [\%] & [\%] \\
\hline Controller from the outside & 0,0 & 5,0 & 0,0 & 2,6 & 1,6 & 2,4 \\
\hline $\begin{array}{l}\text { Controllers in the already existing } \\
\text { department in the organization (e.g. } \\
\text { Department of management accounting) }\end{array}$ & 0,0 & 25,0 & 25,0 & 18,4 & 11,3 & 19,3 \\
\hline $\begin{array}{l}\text { Controllers in the special department } \\
\text { separated for controlling needs (e.g. } \\
\text { controlling department) }\end{array}$ & 75,0 & 45,0 & 58,3 & 71,1 & 64,5 & 59,0 \\
\hline $\begin{array}{l}\text { Controllers located in various places in the } \\
\text { organizational structure }\end{array}$ & 25,0 & 25,0 & 16,7 & 7,9 & 22,6 & 19,3 \\
\hline Total & 100,0 & 100,0 & 100,0 & 100,0 & 100,0 & 100,0 \\
\hline
\end{tabular}

The frequency of using particular forms of inclusion of the controller into the organizational structure depending on the dynamics of the environment is presented in tab. 7. and tab. 8., referring in this way to the M6 model solution: the more dynamic the environment, the more reasonable it is for the main controller's position to take the institutional form. Differences between the results obtained in pairs for the types of environment in both research periods are statistically insignificant. Only a slight increase in the percentage of using the solution consisting of the isolation of controllers located in various places of the organizational structure is observed in a turbulent environment. However, there is no reason to accept the presented hypothesis with reference to the M6 model solution.

Table 7. Forms of including controllers into organizational structure depending on the dynamics of the environment - RES1 (2009). Source: own work based on [Bieńkowska, Kral, Zabłocka-Kluczka, 2011].

\begin{tabular}{|c|c|c|c|c|c|}
\hline RES1 (2009) & \multicolumn{5}{|c|}{ Types of environment [\% of organizations] } \\
\hline \multirow{3}{*}{$\begin{array}{l}\text { Forms of including controllers into } \\
\text { organizational structure }\end{array}$} & stable & $\begin{array}{l}\text { moderately } \\
\text { chanaing }\end{array}$ & changing & turbulent & Total \\
\hline & $\mathrm{N}=20$ & $\mathrm{~N}=57$ & $\mathrm{~N}=61$ & $\mathrm{~N}=10$ & $\mathrm{~N}=148$ \\
\hline & {$[\%]$} & [\%] & {$[\%]$} & {$[\%]$} & {$[\%]$} \\
\hline Controller from the outside & 5,0 & 0,0 & 1,6 & 10,0 & 2,0 \\
\hline $\begin{array}{l}\text { Controllers in the already existing } \\
\text { department in the organization (e.g. } \\
\text { department of management } \\
\text { accounting) }\end{array}$ & 25,0 & 33,3 & 11,5 & 10,0 & 21,6 \\
\hline $\begin{array}{l}\text { Controllers in the special department } \\
\text { separated for controlling needs (e.g. } \\
\text { controlling department) }\end{array}$ & 65,0 & 52,6 & 72,1 & 40,0 & 61,5 \\
\hline $\begin{array}{l}\text { Controllers located in various places in } \\
\text { the organizational structure }\end{array}$ & 5,0 & 14,0 & 14,8 & 40,0 & 14,9 \\
\hline Total & 0,0 & 100,0 & 100,0 & 100,0 & 100,0 \\
\hline
\end{tabular}

Table 8. Forms of including controllers into organizational structure depending on the dynamics of the environment RES2 (2011-2014). Source: own work based on [Bieńkowska 2015].

\begin{tabular}{|l|c|c|c|c|c|}
\hline \multicolumn{1}{|c|}{ RES2 (2011-2014) } & \multicolumn{4}{|c|}{ Types of environment [\% of organizations] } \\
\hline \multirow{2}{*}{$\begin{array}{l}\text { Forms of including controllers into } \\
\text { organizational structure }\end{array}$} & stable & $\begin{array}{c}\text { moderately } \\
\text { changing }\end{array}$ & changing & turbulent & Total \\
\cline { 2 - 6 } & $\mathrm{N}=0$ & $\mathrm{~N}=46$ & $\mathrm{~N}=143$ & $\mathrm{~N}=22$ & $\mathrm{~N}=211$ \\
\cline { 2 - 6 } & {$[\%]$} & {$[\%]$} & {$[\%]$} & {$[\%]$} & {$[\%]$} \\
\hline Controller from the outside & 0,0 & 2,2 & 2,1 & 0,0 & 1,9 \\
\hline $\begin{array}{l}\text { Controllers in the already existing } \\
\text { department in the organization (e.g. } \\
\text { department of management } \\
\text { accounting) }\end{array}$ & 0,0 & 28,3 & 19,6 & 0,0 & 19,4 \\
\hline $\begin{array}{l}\text { Controllers in the special department } \\
\text { separated for controlling needs (e.g. } \\
\text { controlling department) }\end{array}$ & 0,0 & 50,0 & 62,2 & 59,1 & 59,2 \\
\hline $\begin{array}{l}\text { Controllers located in various places in } \\
\text { the organizational structure }\end{array}$ & 0,0 & 19,6 & 16,1 & 40,9 & 19,4 \\
\hline \multicolumn{1}{|c|}{ Total } & 0,0 & 100,0 & 100,0 & 100,0 & 100,0 \\
\hline
\end{tabular}


Another model solution for controlling (M7) concerns the legitimacy of controllers having wide decisionmaking powers. The trend of applied solutions is clearly visible: the percentage of organizations in which the controller has no decision-making powers is decreasing, the number of those in which it has limited powers is increases. Broad decision-making powers are still the rarest solution, although the percentage of organizations applying this solution has slightly increased. Differences between results from RES1 and RES2 are statistically significant - analysis using cross tables and test $\chi^{2}\left(\chi^{2}(2, N=378)=7,502 ; p=0,023^{\star *}\right)$, which means that over the analyzed years $(2009,2011$ 2014) there is a saturation with the model solution, which confirms the $\mathrm{H}$ hypothesis in relation to the $\mathrm{M} 7$ model solution.

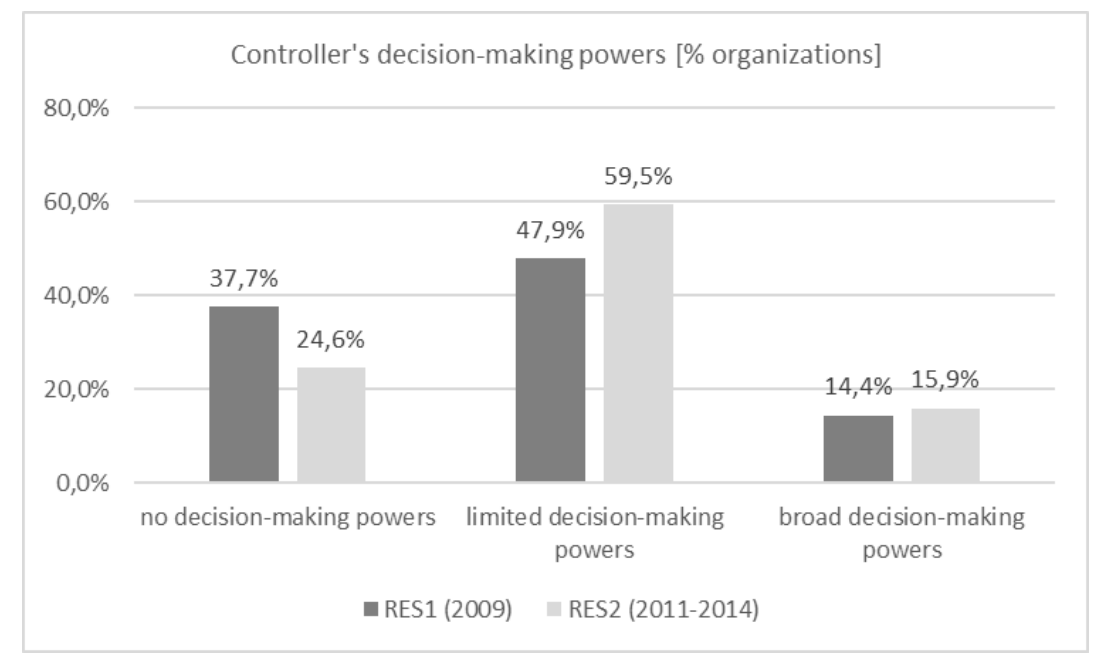

Figure 2. Controller's decision-making powers - comparison of test results from 2009 and in 2011-2014 Source: own work based on [Bieńkowska, Kral, Zabłocka-Kluczka, 2011; Bieńkowska 2015].

According to the model solution (M8), it is reasonable to implement the resultant and investment centers rather than lack of their isolation, it is also appropriate to separate responsibility centers with high decisionmaking independence, while in the context of the model solution (M9) it is reasonable to distinguish various centers of responsibility regardless of situational factors. In tab. 9. the frequency of distinguishing individual types of responsibility centers in both periods is presented. Revenue, resultant and investment centers are more often identified in the surveyed organizations in 2011-2014 than in 2009 (the differences are statistically significant - analysis by cross tables and test chi-squere). It confirms the initial hypothesis with reference to the M8 model solution. Moreover, the use of each type of responsibility centers increases, which proves the diversity of the implemented solutions and confirms the hypothesis in relation to the M9 model solution. Unfortunately, it is not possible (due to the limited scope of research from 2009) to verify the hypothesis with reference to the M10 model solution (M10: it is reasonable that the centers of responsibility are more aggregated than fragmented).

Table 9. Frequency of distinguishing individual types of responsibility centers - comparison of survey results from 2009 and 2011-2014. Source: own work based on [Bieńkowska, Kral, Zabłocka-Kluczka, 2011; Bieńkowska 2015].

\begin{tabular}{|c|c|c|c|}
\hline \multirow{2}{*}{$\begin{array}{c}\text { Type of responsibility } \\
\text { center }\end{array}$} & \multicolumn{2}{|c|}{ Use [\% organizations] } & \multirow[t]{2}{*}{$\chi^{2}$ test results } \\
\hline & RES (2009) & $\begin{array}{c}\text { RES (2011- } \\
2014)\end{array}$ & \\
\hline production & 45,7 & 50,2 & $\chi^{2}(1, N=393)=0,770 ; p=0,380$ \\
\hline cost & 76,2 & 76,9 & $\chi^{2}(1, N=393)=0,022 ; p=0,883$ \\
\hline revenue & 37,8 & 51,5 & $\chi^{2}(1, N=393)=7,250 ; p=0,007^{* *}$ \\
\hline resultant & 51,8 & 60,7 & $\chi^{2}(1, N=393)=3,067 ; p=0,080$ \\
\hline investment & 24,5 & 37,1 & $\chi^{2}(1, N=393)=6,936 ; p=0,008^{* *}$ \\
\hline none were separated & 7,3 & 11,7 & $\chi^{2}(1, N=394)=2,099 ; p=0,147$ \\
\hline
\end{tabular}

\section{IMPLEMENTATION OF MODEL INSTRUMENTAL CONTROLLING SOLUTIONS}

In the research conducted in 2011 , a synthetic guideline was adopted regarding the model instrumental solutions of controlling (in terms of the quality of these solutions and the efficiency of controlling, as well as the quality of management and organizational performance):

- $\quad(\mathrm{M} 11)$ it is reasonable to implement as many instruments of controlling as possible. 
The analyzes allowed to compare the frequency of application of the 5 main controlling instruments (budgeting, cost accounting, income statement, information and decision system and analysis of deviations), as well as 6 additional ones. A summary of the frequency of use of these instruments in both research periods is presented in tab. 10. It turns out that in the case of only two instruments, there has been a decrease in the percentage of their use in the analyzed period. However, the differences are not statistically significant. Moreover, in the case of 5 instruments, the increase in the frequency of their use is statistically significant (analysis using cross tables and $\chi^{2}$ test), which allows for accepting the hypothesis with reference to the $\mathrm{M} 11$ model solution: it is reasonable to implement as many instruments of controlling as possible. That is because the increase in the number of uses of individual instruments signifies an increase in the total number of controlling instruments used in the organization.

Table 10. Frequency of using controlling instruments - comparison of test results between 2009 and 2011-2014. Source: own work based on [Bieńkowska, Kral, Zabłocka-Kluczka, 2011; Bieńkowska 2015].

\begin{tabular}{|c|c|c|c|}
\hline \multirow[b]{2}{*}{ Instrument } & \multicolumn{2}{|c|}{ Use [\% of organizations] } & \multirow[b]{2}{*}{$\chi^{2}$ test results } \\
\hline & $\begin{array}{c}\text { RES } \\
(2009)\end{array}$ & $\begin{array}{l}\text { RES (2011- } \\
2014)\end{array}$ & \\
\hline budgeting (including costs budgeting) & 92,7 & 88,5 & $\chi^{2}(1, N=398)=1,944 ; p=0,136$ \\
\hline $\begin{array}{l}\text { cost accounting (np. traditional cost } \\
\text { accounting, variable costs, target } \\
\text { activities) }\end{array}$ & 89,0 & 82,9 & $\chi^{2}(1, N=398)=2,899 ; p=0,089$ \\
\hline $\begin{array}{l}\text { income statement (np. traditional, short- } \\
\text { term, two and more dimensional) }\end{array}$ & 54,3 & 76,9 & $\chi^{2}(1, N=398)=22,590 ; p<0,001^{* *}$ \\
\hline information and reporting system & 80,5 & 88,0 & $\chi^{2}(1, N=398)=4,289 ; p=0,038^{* *}$ \\
\hline $\begin{array}{l}\text { analysis of deviations between values } \\
\text { achieved and planned ones }\end{array}$ & 76,8 & 78,2 & $\chi^{2}(1, N=398)=0,105 ; p=0,746$ \\
\hline transfer prices & 28,0 & 41,5 & $\chi^{2}(1, N=398)=7,526 ; p=0,006^{* *}$ \\
\hline break-even analysis & 56,7 & 57,3 & $\chi^{2}(1, N=398)=0,012 ; p=0,912$ \\
\hline investment efficiency calculation & 51,8 & 48,3 & $\chi^{2}(1, N=398)=0,483 ; p=0,487$ \\
\hline VBM analysis & 14,7 & 17,9 & $\chi^{2}(1, N=398)=0,721 ; p=0,396$ \\
\hline risk analysis & 21,6 & 41,9 & $\chi^{2}(1, N=398)=11,194 ; p=0,001^{* *}$ \\
\hline $\begin{array}{l}\text { methods of strategic analysis and } \\
\text { strategy formulation }\end{array}$ & 21,3 & 32,1 & $\chi^{2}(1, N=398)=5,530 ; p=0,019^{* *}$ \\
\hline
\end{tabular}

Interestingly, an additional analysis was made concerning the frequency of application of the main controlling instruments (i.e. budgeting, cost accounting, income statement, information and reporting system and deviation analysis) in organizations that did not implement controlling. It turns out that in these organizations there has been a much more rapid increase in the percentage of use of these instruments in the period under consideration, i.e. the frequency of application was as follows:

- budgeting - increase from 40,8\% in 2009 to $58,2 \%$ in 2011-1014;

- cost accounting - increase from 45,1\% in 2009 to $81,6 \%$ in 2011-1014;

- income statement - increase from $19,0 \%$ in 2009 to $69,5,2 \%$ in 2011-1014;

- information and reporting system - increase from $45,1 \%$ in 2009 to $69,5 \%$ in $2011-1014$;

- deviation analysis - increase from $19,7 \%$ in 2009 to $37,6 \%$ in $2011-1014$.

All differences are statistically significant (analysis with cross tables and test $\chi^{2}$ ), which shows a significant increase in the importance of these instruments in contemporary organizations functioning in Poland.

\section{CONCLUSIONS}

The presented model solutions can be divided into universal and consistent with the contingency- theoretical approach. The first group includes the following model solutions: M3, M7, M8, M9, M10, M11, and the second group consists of: M1, M2, M4, M5, M6. The conducted comparative studies prove that in relation to all (verifiable in comparative studies) model solutions of a universal nature, there was a statistically significant increase in the degree of their implementation in organizations operating in Poland in the observed time (2009; 2011-2014). However, in the case of model solutions corresponding to the contingency-theoretical approach, such unambiguous conclusion cannot be formed, although the observed trends are consistent with the assumptions. In connection with the above, it seems that the hypothesis presented at the beginning: In the process of striving for excellence (in time) there is a spontaneous increase in the degree of implementation of the model controlling solutions due to the maximization of the benefits possible to obtain due to the implementation of controlling can be partially accepted based on comparative research. This proves that the selection and implementation of such controlling solutions that result in the highest quality of management and the effectiveness of the organization as a whole is possible to achieve through self-learning of the organization. Of course, the carried-out research has some limitations. First of all, the overall research did not allow for a comprehensive comparison of the frequency of applying all model controlling solutions due to the 
limited scope of the first part of the research. In addition, the sample cannot be considered as representative, which does not allow for inference referring to the entire population of organizations operating in Poland. Despite this, in both surveys, efforts have been made to ensure that it is diversified enough to be the basis for data analysis and formulating conclusions about the processes taking place in the area of controlling in the surveyed organizations. At the same time, it seems that the issue of improving controlling solutions in the organization and striving for its excellence requires further in-depth research work.

\section{REFERENCES}

[1] Becker W., Baltzer B., Ulrich P. (2011), Controlling as a science in Germany - retrospective, status quo and outlook, Singiunum Revija, vol. 8(2).

[2] Bieńkowska A. (2014), „Poprawność rozwiązań controllingu indywidualizm versus uniwersalizm”, Marketing i Rynek, nr 5.

[3] Bieńkowska A. (2016), „Organizacje zarządzane controllingowo: wyniki badań empirycznych". Zarządzanie i Finanse - Journal of Management and Finance, R. 14, nr 2, cz. 1, s. 7-19.

[4] Bieńkowska A. (2015), Analiza rozwiązań i wzorce controllingu w organizacji, Oficyna Wydawnicza Politechniki Wrocławskiej (PWr), Wrocław.

[5] Bieńkowska A., Kral Z., Zabłocka-Kluczka A. (2011), "Controlling solutions in Polish enterprises - chosen study results", Controlling, Nr. 10(23). , s. 539-546.

[6] Bieńkowska A., Tworek K., Zabłocka-Kluczka A. (2018), "Information technology reliability influence on controlling excellence", International Journal of Digital Accounting Research. 2018, in press.

[7] Bieńkowska A., Tworek K., Zabłocka-Kluczka A. (2019), "IT reliability and its influence on the results of controlling comparative analysis of organizations functioning in Poland and Switzerland". Information Systems Management, in press.
[8] Bieńkowska A., Zgrzywa-Ziemak A. (2011), Współczesne metody zarządzania w przedsiębiorstwach funkcjonujących $w$ Polsce - identyfikacja stanu istniejącego, Współczesne metody zarządzania w teorii i praktyce, M. Hopej, Z. Kral (red.), Oficyna Wydawnicza PWr, Wrocław.

[9] Bragg S.M. (2004), Controller's Guide. Roles and responsibilities for the first year, Wiley \& Sons Inc., New Jersey.

[10] Chalastra M. (2010), „Audyt systemu controllingu”, Controlling Rachunkowość Zarządcza, nr 10.

[11] Goliszewski J. (1991), „Controlling - system controllingu (V)”, Przegląd Organizacji, $\mathrm{nr} 4$

[12] Grudziński J. (2008), „Meandry wdrażania idei controlling w Południowym Koncernie Energetycznym S.A.", Controlling i Rachunkowośc zarządcza, nr 3.

[13] Haładryj M. (1991), "Controlling - metoda i filozofia nowoczesnego zarządzania przedsiębiorstwem”, Handel Wewnętrzny, nr 3.

[14] Horvath P. (2002), Controlling, Verlag Franz Vahlen, München.

[15] Horvath P. (2009), What is "German controlling", Cost management, Nr. 2(23).

[16] Jackson J.H. (1949), The growth of the controllership function, Controllership in modern management, B.F. Thornton, C.H. Hull, R.D. Irwin, Chicago.

[17] Lichtarski J.M., Nowosielski K. (2005), „Modele controllingu dla małych i średnich przedsiębiorstw”, Organizacja i Kierowanie, nr 2.

[18] Nesterak J. (2002), Controlling. System oceny ośrodków odpowiedzialności, ANVIX, Kraków.

[19] Nowak E. (2004), „Rozwój controllingu w świetle tematyki konferencji polanickich”, Rachunkowość zarządcza i controlling w warunkach integracji z Unią Europejską, E. Nowak (red.), Prace Naukowe Akademii Ekonomicznej im. Oskara Langego we Wrocławiu, nr 1019.

[20] Nowak M. (2008), Controlling personalny w przedsiębiorstwie, Oficyna Ekonomiczna Wolters Kluwer, Kraków.

[21] Tworek K. (2019), Aligning IT with Business: IT Reliability as an Indicator for Employee Commitment and Organizational Performance, Springer, Berlin, Heidelberg, in press.

[22] Wierzbicki K. (1994), "Controlling w zarządzaniu przedsiębiorstwem”, Ekonomika i Organizacja Przedsiębiorstwa, nr 3.

\title{
Kontroling - težnja ka izvrsnosti Implementacija modela rešenja u organizacijama koje posluju u Poljskoj
}

\author{
Agnieszka Bieńkowska
}

Primljen (28.11.2018.); Recenziran (08.01.2019.); Prihvaćen (05.02.2019.)

\begin{abstract}
Abstrakt
U članku se razmatra pitanje kontrole promena tokom vremena u organizacijama koje posluju u Poljskoj. Upućeno je na rešenja kontroling modela koje je predložila A. Bieńkowska [2015], koji bi trebalo da obezbedi da se maksimalne moguće koristi od implementacije kontrolinga ostvare sa određenim troškovima u tom pogledu. Pretpostavljeno je da bi u procesu postizanja izvrsnosti kontrole trebalo da se poveća procenat organizacija koje koriste modelskih rešenja, s obzirom na činjenicu da upotreba takvih rešenja rezultira povećanjem efikasnosti kontrolinga, a zatim povećanjem kvaliteta upravljanja i organizacioni učinak. Da bi se verifikovala usvojena hipoteza, sprovedene su komparativne studije o učestalosti korišćenja modelskih rešenja kontrolinga u 2009. i 2011-2014. Uzorak nije bio reprezentativan, već diversifikovan i obuhvatio je 306 istraživačkih organizacija iz 2009. godine (164 su prijavile upotrebu kontrolinga) i 412 organizacija u studijama iz 2011-2014. (gde je 238 izjavilo da koriste kontroling). Statistička verifikacija razlika u obe grupe izvršena je korišćenjem unakrsnih tabela sa hi-kvadrat statistikom. Rezultati studije omogućuju da se prihvati hipoteza da u procesu težnje ka izvrsnosti (u vremenu) dolazi do spontanog povećanja stepena implementacije modela upravljačkih rešenja zbog maksimiziranja pogodnosti koje je moguće dobiti zbog sprovođenje kontrole.
\end{abstract}

Ključne reči: kontroling, rešenja za modeliranje, izvrsnost 